\title{
Splanchnic Bioprocessing: An Innovative Philosophy of Intake Regulation in Ruminants vs. Nonruminants
}

\section{Akbar Nikkhah*}

Chief Highly Distinguished Professor, Department of Animal Sciences, University of Zanjan, Iran

The objective of this perspective article was to describe splanchnic bioprocessing of substrates as a fundamental effector of nutrient intake regulation in ruminants. And how that compares with nonruminants? Feed costs constitute about half the total management investments in modern ruminant farms. This cost may, however, be underestimated. when inappropriate feedstuffs or feeding strategies are used for; costs will rise because health and longevity are compromised.

To meet nutrient requirements of a high-producing lactating cow or growing cattle at certain milk yield and body growth rate, accurate prediction of feed intake is a must [1-4]. This requires a profound insight into animal and non-animal factors affecting nutrient intake [3]. The contribution of such factors to feed intake control in certain productive and environmental conditions must also be quantified. Many effectors of feed intake are still largely unknown. In addition, the magnitude of the somehow known factors needs more quantification and modification under varying production scenarios [4]. Therefore, reliable nutrient and feed intake prediction has been a difficult task in ruminants. Splanchnic differences in nutrient metabolism do exist between ruminants and nonruminants that greatly contribute to the different mechanisms controlling nutrient intake in ruminants. Ruminants indeed possess higher metabolic rate in portal and mesenteric derived viscera plus liver, when compared with nonruminants.

Predicting feed intake is thus more exigent in ruminants than in nonruminants. A multitude of visceral variables such as rumen $\mathrm{pH}$, osmolarity, and gastrointestinal outflow rate affect the extent and rate of nutrient utilization by rumen microbes. More critically, these variables interact with each other either positively, negatively, or additively. Nevertheless, measuring such interactions is difficult in vivo. Accurate predictions of feed intake require accurate forecast of the rumen conditions (e.g., $\mathrm{pH}, \mathrm{VFA}$ and ammonia production, and microbial protein synthesis). Thus, expectedly what scientists plan to achieve in rumen, postrumen and the periphery using computerized feeding programs are not essentially realizable on farms. Differential visceral and splanchnic metabolism of substrates (i.e., turnover in portal drained viscera and liver) greatly contributes to such discrepancies.

The intestinal nutrient digestion differs considerably in capacity and efficiency between ruminants and nonruminants [5]. Moreover, ruminant diets are highly fibrous and less starchy than nonruminant diets. As a result, ruminants have been expected to possibly not develop as a high small intestinal amylolytic capacity as nonruminants. When starchy diets especially containing hard cereal grains are fed, particularly in high-producing ruminants with high intake levels, the small intestine could host much partially-hydrolyzed or intact starch. Furthermore, the ruminant small intestine is debatably not capable to efficiently assimilate the starch overflow [6,7]. Furthermore, the small intestinal nutrient assimilation in ruminants depends on different factors including energy and protein intake levels and forms. All in all, numerous rumen and gastrointestinal variables, especially in circadian rhythmic terms, must be accurately quantified for nutrient and feed intake to be unfailingly predicted.

In a nutshell, what signify the comparative intake regulation in ruminants and nonruminants include massive substrate bioprocessing in ruminants undergoing demanding lactation, metabolic pressure, and pregnancy. This uniqueness must be rhythmically monitored for consistent accuracy in feed intake prediction models.

\section{Acknowledgments}

The Iran's Ministry of Science Research and Technology, National Elite Foundation, and University of Zanjan are gratefully acknowledged for supporting the author's global programs of optimizing science edification in the new millennium.

\section{References}

1. Nikkhah A (2011) Ruminant chronophysiological management: an emerging bioscience. Open Access Anim Physiol 3: 9-12.

2. Nikkhah A (2013) Chronophysiology of ruminant feeding behavior and metabolism: an evolutionary review. Biol Rhythm Res 44: 197-218.

3. Nikkhah A (2012) Time of Feeding an Evolutionary Science, Lap Lambert Academic Publishing, GmbH \& Co. KG, Germany.

4. Nikkhah A (2014) Review: Ruminant feed intake regulation evolution: Chronophysiological rhythms perspectives. Biol Rhythm Res 45: 563-577.

5. Harmon DL (1993) Nutritional regulation of postruminal digestive enzymes in ruminants. J Dairy Sci 76: 2102-2111.

6. Huntington GB (1997) Starch utilization by ruminants: from basics to the bunk J Anim Sci 75: 852-867.

7. Ørskov ER (1986) Starch digestion and utilization in ruminants. J Anim Sci 63 1624-1633.
*Corresponding author: Akbar Nikkhah, Chief Highly Distinguished Professor Department of Animal Sciences, Faculty of Agricultural Sciences, University of Zanjan, Zanjan, Iran, National Elite Foundation, Tehran, Iran, Tel: +98-24-350328-01; Fax: +98-24-350-332-02; E-mail: nikkhah@znu.ac.ir

Received January 20, 2015; Accepted January 21, 2015; Published January 23, 2015

Citation: Nikkhah A (2015) Splanchnic Bioprocessing: An Innovative Philosophy of Intake Regulation in Ruminants vs. Nonruminants. J Bioprocess Biotech 5: e119 doi:10.4172/2155-9821.1000e120

Copyright: (c) 2015 Nikkhah A. This is an open-access article distributed under the terms of the Creative Commons Attribution License, which permits unrestricted use, distribution, and reproduction in any medium, provided the original author and source are credited. 